\title{
The International Criminal Court and Sexual Violence: Between Aspirations and Reality
}

\author{
Tanja Altunjan \\ Berlin, Germany \\ Corresponding author: tanja.altunjan@gmail.com
}

(Received 12 July 2021; accepted 13 July 2021)

\begin{abstract}
The adoption of the Rome Statute of the International Criminal Court (ICC) was widely lauded as a success with regard to the recognition and potential prosecution of conflict-related sexual violence. More than twenty years later, however, many observers are disillusioned with the ICC's dire track record concerning the implementation of its progressive legal framework. In many cases, the Court and particularly its Prosecutor have been criticized for failing to adequately address and prioritize sexual violence, culminating in only a single final conviction since 2002. Nevertheless, the ICC's emerging practice shows progress with regard to the conceptual understanding of conflict-related sexual violence and the realization of the Statute's full potential in ensuring accountability for sexual crimes. Taking into account the evolving jurisprudence, the Article explores the persisting challenges and the perceived gap between aspirations and reality regarding the prosecution of sexual violence at the ICC.
\end{abstract}

Keywords: Sexual violence; gender-based violence; International Criminal Court; gender; persecution; reproductive violence; forced pregnancy

\section{A. Introduction}

The widespread occurrence of sexual violence in armed conflicts and other macro-criminal contexts is undisputed. ${ }^{1}$ Since the mid-1990s, practitioners, experts, and activists alike have attempted to make use of the international criminal legal framework in order to find repressive responses to conflict-related sexual violence. The adoption of the Rome Statute of the International Criminal Court (ICC) in 1998 and its entry into force in 2002 was widely celebrated as an important step towards ending impunity for sexual crimes under international law. Referring to the ICC's establishment, former Prosecutor of the International Criminal Tribunals for the former Yugoslavia (ICTY) and Rwanda (ICTR), Richard Goldstone, declared that "gender crimes are now given the recognition they were denied for so many years ... It is my hope that the history of impunity

\footnotetext{
${ }^{1}$ See, e.g., Kelly D. Askin, War Crimes Against Women: Prosecution in International War Crimes Tribunals (1997); Susan Brownmiller, Against Our Will: Men, Women and Rape 31-113 (1975); Christine Chinkin, Rape and Sexual Abuse of Women in International Law, 5 EUR. J. INT'L L. 326, 327-28 (1994); Rhonda Copelon, Surfacing Gender: Re-Engraving Crimes Against Women in Humanitarian Law, 5 Hastings Women's L. J. 243, 243-45 (1994); Judith Gail Gardam \& Michelle J. JARVis, WOMEN, ARMEd CONFLICT AND INTERNATIONAL LAW 27-29 (2001). The ideas put forward in this Article partly originate from Tanja Altunjan, Reproductive Violence and International Criminal LaW (2021).

(C) The Author(s), 2021. Published by Cambridge University Press on behalf of the German Law Journal. This is an Open Access article, distributed under the terms of the Creative Commons Attribution licence (http://creativecommons.org/licenses/by/4.0/), which permits unrestricted re-use, distribution, and reproduction in any medium, provided the original work is properly cited.
} 
for gender crimes under international criminal law will resolutely be replaced in the future by accountability and deterrence and prevention." ${ }^{2}$

Indeed, the ICC Statute enumerates a wide range of sexual crimes and demonstrates an unprecedented degree of gender sensitivity in international criminal law. Nevertheless, these potentials have not been fully translated into legal practice. Almost twenty years after its establishment, the ICC has managed to procure only a single, final conviction for sexual crimes. ${ }^{3}$ This Article addresses the gap between aspirations and realities of the ICC's response to conflict-related sexual and gender-based violence. The first part explores the drafting process and the potentials of the ICC Statute with respect to the prosecution of sexual crimes. The second part examines the ICC's track record thus far and highlights problematic features of its practice and jurisprudence on such crimes. Finally, the third part of this Article identifies recent progressive developments as well as persisting challenges.

\section{B. Great Expectations: Ending Impunity for Conflict-Related Sexual Violence Through the ICC}

As Richard Goldstone's statement illustrates, many observers had high hopes for the first permanent international criminal court. Its creation was deemed a great success, especially in light of the difficult negotiations during the 1998 Rome Conference and in the preceding years. After a brief account of these negotiations in their historical context, the following section depicts the ICC's progressive legal framework on sexual crimes and other gender issues.

\section{Negotiating a Gender-Sensitive Statute for the ICC}

The adoption of the ICC Statute was heavily influenced by the creation and practice of the ICTY and the ICTR, established in 1993 and $1994 .{ }^{4}$ In a political climate of progressive advancement of international law, these developments paved way for a permanent international criminal court. With respect to sexual violence in particular, the atrocities documented during the Yugoslav wars and the genocide in Rwanda as well as the subsequent international outcry heavily influenced the ICC negotiations.

Prior to the ad hoc tribunals' establishment, international criminal law had remained almost completely silent on sexual and gender-based violence, both on paper and in practice. For example, the word "rape" did not appear in the judgment of the Nuremberg International Military Tribunal. Its Charter, widely considered as the "birth certificate" of international criminal law, ${ }^{5}$ also did not explicitly refer to sexual crimes, though they could have been prosecuted under more general provisions such as the crime against humanity of other inhumane acts ${ }^{6}$ and the war crime of ill-treatment. ${ }^{7}$ Against this background, the inclusion of rape as a crime against humanity

\footnotetext{
${ }^{2}$ Richard J. Goldstone, Prosecuting Rape as a War Crime, 34 CASE WeStern Reserve J. InT'L L. 277, 285 (2002).

${ }^{3}$ ICC, Prosecutor v. Ntaganda, ICC-01/04-02/06, Judgment (Jul. 8, 2019), https://www.icc-cpi.int/CourtRecords/CR2019_ 03568.PDF; ICC, Prosecutor v. Ntaganda, ICC-01/04-02/06 A A2, Appeals Judgment (Mar. 30, 2021), https://www.icc-cpi.int/ CourtRecords/CR2021_03027.PDF.

${ }^{4}$ S.C. Res. 827 (May 25, 1993); S.C. Res. 955 (Nov. 8, 1994).

${ }^{5}$ Gerhard Werle \& Florian Jeßberger, Principles of International Criminal Law margin no. 16 (4th ed. 2020).

${ }^{6}$ Charter of the International Military Tribunal, 59 Stat. 1546, 82 U.N.T.S. 284, art. 6(c) (Aug. 8, 1945). See AsKIN, supra note 1, at 142; M. Cherif BAssiouni, Crimes Against Humanity: Historical Evolution and CONTEMPORARY Application 425 (2011); AnNe-Marie L.M. De Brouwer, Supranational Criminal Prosecution of Sexual Violence: The ICC And the Practice of the ICTY AND The ICTR 7 (2005); Alexander Schwarz, Das VÖLKERRECHTLICHE SEXUALSTRAFrecht: SEXUALISIERTE UND GESCHLECHTSBEZOGENE GEWALT VOR DEM INTERNATIONALEN STRAFGERICHTSHOF 104 (2019); WERLE \& JEßBERGER, supra note 5, margin no. 1084.

${ }^{7}$ Charter of the International Military Tribunal, 59 Stat. 1546, 82 U.N.T.S. 284, art. 6(b) (Aug. 8, 1945). See SCHWARZ, supra note 6 , at 104 .
} 
in Control Council Law No. 10 of 1945, the common legal basis for further trials in the occupied zones in Germany, ${ }^{8}$ was an important breakthrough, even though no prosecutions under this specific provision followed. ${ }^{9}$

The ICTY and ICTR Statutes both enumerated rape as a crime against humanity, ${ }^{10}$ and the ICTR Statute additionally listed rape, enforced prostitution, and any form of indecent assault as war crimes. ${ }^{11}$ Furthermore, both tribunals extensively addressed sexual violence in their judgments and established important precedents. ${ }^{12}$ Despite these progressive developments in the late 1990s, issues of sexual violence and gender sensitivity in general remained controversial during the drafting process for the ICC Statute. When it became clear that gender issues would receive very limited attention, ${ }^{13}$ a group of women's rights activists and organizations formed the Women's Caucus for Gender Justice in the International Criminal Court and began to lobby for the inclusion of a gender perspective in the Statute. The Women's Caucus successfully recommended an expansion of the list of sexual and gender-based crimes. ${ }^{14}$ It also succeeded in detaching sexual crimes from "outrages upon personal dignity", thus abandoning the problematic notion that sexual crimes violate the victim's "honor". ${ }^{15}$

\section{The Potentials of the ICC Statute Regarding the Prosecution of Sexual Violence \\ 1. Explicit Criminalization of Sexual Violence}

The adoption of the ICC Statute certainly represents major progress with respect to the possibility for prosecuting a wide range of sexual and gender-based offenses. For the first time in international criminal law, the Statute not only lists rape and enforced prostitution, but enumerates several specific crimes against humanity and war crimes, namely rape, sexual slavery, enforced prostitution, forced pregnancy, and enforced sterilization. ${ }^{16}$ Additionally, both provisions include a residual crime covering similar acts of sexual violence not explicitly enumerated. ${ }^{17}$ This allows for a dynamic interpretation and application of the ICC Statute. Furthermore, the

\footnotetext{
${ }^{8}$ See Werle \& JeßBerger, supra note 5 , at margin no. 38.

${ }^{9}$ See Alexandra Adams, Der Tatbestand der Vergewaltigung im Völkerstrafrecht 207 (2013); De Brouwer, supra note 6, at 8; Catherine N. Niarchos, Women, War, and Rape: Challenges Facing the International Tribunal for the Former Yugoslavia, 17 Hum. RTs. QuARTERLY 649, 677 (1995); SCHWARZ, supra note 6, at 109.

${ }^{10}$ Statute of the International Criminal Tribunal for the Former Yugoslavia, U.N. Doc. S/25704, art. 5(g) (1993); Statute of the International Criminal Tribunal for Rwanda, U.N. Doc. S/RES/955, art. 3(g) (1994).

${ }^{11}$ Statute of the International Criminal Tribunal for Rwanda, U.N. Doc. S/RES/955, art. 4(e) (1994).

${ }^{12}$ See, e.g., ICTR, Prosecutor v. Akayesu, Case No. ICTR-96-4-T, Judgment (Sep. 2, 1998), https://unictr.irmct.org/sites/ unictr.org/files/case-documents/ictr-96-4/trial-judgements/en/980902.pdf; ICTY, Prosecutor v. Mucić et al., Case No. IT96-21-T, Judgment (Nov. 16, 1998), https://www.icty.org/x/cases/mucic/tjug/en/981116_judg_en.pdf; ICTY, Prosecutor v. Furundžija, Case No. IT-95-17/1-T, Judgment (Dec. 10, 1998), https://www.icty.org/x/cases/furundzija/tjug/en/furtj981210e.pdf. For an overview, see Kelly D. Askin, Prosecuting Wartime Rape and Other Gender-Related Crimes Under International Law: Extraordinary Advances, Enduring Obstacles, 21 BERKELEY J. INT'L L. 288, 317-46 (2003).

${ }^{13}$ See Barbara Bedont \& Katherine Hall-Martinez, Ending Impunity for Gender Crimes Under The International Criminal Court, 6 Brown J. World AfF. 65, 66-67 (1999); Valerie Oosterveld, The Making of a Gender-Sensitive International Criminal Court, 1 INT'L L. F. DU DroiT INT'L 38, 38-39 (1999); William Pace \& Jennifer Schense, The Coalition of the International Criminal Court at the Preparatory Commission, in The INTERNATIONAL Criminal CourT, Vol. 2: Elements of Crimes and Rules of Procedure And Evidence 705, 719 (Roy S. Lee ed., 2000).

${ }^{14}$ Women's Caucus for Gender Justice, Recommendations and Commentary for December 1997 PrepCom on the Establishment of an International Criminal Court, United Nations Headquarters December 1-12, 1997, at 31 (1997), on file with author.

${ }^{15}$ See Bedont \& Hall-Martinez, supra note 13 , at 73.

${ }^{16}$ Rome Statute of the International Criminal Court, 2187 U.N.T.S. 3, at arts. 7(1)(g), 8(2)(b)(xxii), \& 8(2)(e)(vi) (Jul. 17, 1998). On the substantive, procedural, and institutional framework of the ICC pertaining to sexual crimes and gender issues, see Altunjan, supra note 1, at 54-57 (2021).

${ }^{17} I$ d. at art. 7(1)(g) ("any other form of sexual violence of comparable gravity"); art. 8(2)(b)(xxii) ("any other form of sexual violence also constituting a grave breach of the Geneva Conventions"); art. 8(2)(e)(vi) ("any other form of sexual violence also constituting a serious violation of article 3 common to the four Geneva Conventions").
} 
Statute explicitly criminalizes the crime against humanity of enslavement with special regard to trafficking of women and children. ${ }^{18}$ It also includes the first explicit criminalization of persecution on gender grounds as a crime against humanity, ${ }^{19}$ which represents an important step towards a more gender-sensitive international criminal legal framework. ${ }^{20}$

Explicit criminalization is important because "the ability to eliminate a wrong is contingent on it first being 'named"' ${ }^{21}$ Although it has long been possible to prosecute sexual violence under more general provisions, this opportunity was rarely seized in practice. Against this background, the explicit criminalization of different manifestations of sexual violence ensures that such acts are understood as potential criminal conduct deserving investigation and prosecution. ${ }^{22}$ Moreover, enumerating specific crimes recognizes the unique harm entailed in those acts. ${ }^{23}$ This relates to the expressive function of international criminal law, which is not only relevant in the context of prosecution and punishment, ${ }^{24}$ but also comes into play in the precise qualification of offenses. ${ }^{25}$ By explicitly criminalizing a certain conduct, the international community acknowledges that it may amount to "grave crimes [which] threaten the peace, security and well-being of the world." 26 Furthermore, a specific criminalization under international law "surfaces"27 the gendered experiences suffered by victims in conflict scenarios: It not only allows for an adequate assessment of the perpetrators' criminal responsibility, but also acknowledges the victims' experiences and highlights the unique harm they suffered. ${ }^{28}$ This is also significant in the context of transitional justice initiatives and post-conflict scenarios: Considering the stigmatization often suffered by survivors of sexual violence, a precise qualification of crimes may benefit

\footnotetext{
${ }^{18} I d$. at art. $7(2)(\mathrm{c})$.

${ }^{19}$ Id. at art. $7(1)(\mathrm{h})$.

${ }^{20}$ See Rosemary Grey, Jonathan O’Donohue, Indira Rosenthal, Lisa Davis, \& Dorine Llanta, Gender-Based Persecution as a Crime Against Humanity: The Road Ahead, 17 J. InT'L Crim. Just. 957 (2019); Katrin Kappler, Die Verfolgungen wegen

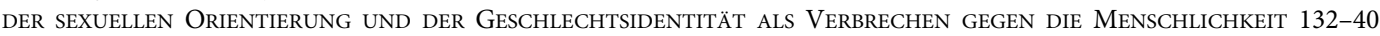
(2019); SCHWARZ, supra note 6, at 369-408.

${ }^{21}$ Rebecca J. Cook \& Simone Cusack, Gender Stereotyping: Transnational Legal Perspectives 39 (2011). On the benefits of explicit criminalization, see in more detail ALTUNJAN, supra note 1, at 213-15.

${ }^{22}$ Rhonda Copelon, Gender Crimes as War Crimes: Integrating Crimes Against Women into International Criminal Law, 46 McGill L. J. 217, 234 (2000). See also Rosemary Grey, Prosecuting Sexual and Gender-Based Crimes at the international Criminal Court: Practice, Progress and Potential 103-04 (2019).

${ }^{23}$ See Wiebke Rückert \& Georg Witschel, Genocide and Crimes Against Humanity in the Elements of Crimes, in International and National Prosecution of Crimes Under International Law: Current Developments 59, 81 (Horst Fischer et al. eds., 2001). With regard to forced marriage, see Annie Bunting \& Izevbuwa Kehinde Ikhimiukor, The Expressive Nature of Law: What We Learn From Conjugal Slavery to Forced Marriage in International Criminal Law, 18 INT'L Crim. L. Rev. 331 (2018).

${ }^{24}$ See, e.g., Margaret M. deGuzman, An Expressive Rationale for the Thematic Prosecution of Sex Crimes, in THEMATIC Prosecution of International Sex Crimes 11 (Morten Bergsmo ed., 2012); Mark A. Drumbl, Atrocity, Punishment, and International LaW 173-79 (2007); AzIZ Epik, Die Strafzumessung bei Taten Nach dem VÖlKERSTRAFGESETZBUCH 149-52 (2017); ANDREAs WERKMEISTER, STRAFTHEORIEN IM VÖLKERSTRAFRECHT 272-347 (2015).

${ }^{25}$ See also Kai Ambos, Genocide (Article 28B), Crimes Against Humanity (Article 28C), War Crimes (Article 28D) and the Crime of Aggression (Article 28M), in The African Criminal CourT 31, 40 (Gerhard Werle \& Moritz Vormbaum eds., 2017); Bunting \& Ikhimiukor, supra note 23.

${ }^{26}$ Rome Statute, supra note 16, preamble para. 3. Similarly, see MAJA KirILOVA ERIKSSON, ReProduCtive FreEdOM: IN THE CONTEXT Of International Human Rights And Humanitarian LaW 480 (2000); Rosemary Grey, The ICC's First 'Forced Pregnancy' Case in Historical Perspective, 15 J. INT'L CRIM. Just. 905, 927 (2017); Valerie Oosterveld, Evaluating the Special Court for Sierra Leone's Gender Jurisprudence, in The Sierra LeOne Special Court and ITS Legacy: The ImPact for Africa AND International CRiminal LAw 234, 235 (Charles Chernor Jalloh ed., 2013).

${ }^{27}$ Copelon, supra note 1 .

${ }^{28}$ In the context of forced marriage, see Bunting \& Ikhimiukor, supra note 23; Valerie Oosterveld, Forced Marriage and the Special Court for Sierra Leone: Legal Advances and Conceptual Difficulties, 2 J. INT'L HUMANITARIAN LEGAL STUD. 127, 139-41 (2011).
} 
the process of rehabilitation and reconciliation by way of emphasizing the coercive nature and counteracting the notion of voluntary relations with perpetrators. ${ }^{29}$ Additionally, specific criminalization allows for the practical acknowledgement of victims' experiences through the instruments of victim participation and reparation. ${ }^{30}$

\section{Gender Sensitivity in the ICC Legal Framework}

Apart from the explicit criminalization of sexual violence, the ICC Statute and the accompanying documents, the Elements of Crimes and the Rules of Procedure and Evidence contain several important provisions aimed at ensuring that sexual crimes are prosecuted in an effective and gender-sensitive manner. Pertaining to substantive law, the Elements of Crimes define rape in a gender-neutral manner, ${ }^{31}$ clarifying that the crime does not exclusively apply to women and girls. With regard to genocide, they also clarify that the genocidal act of "causing serious bodily or mental harm" under Article 6(b) of the ICC Statute may include rape and sexual violence. $^{32}$

With a view to procedural law, the Rules of Procedure and Evidence state, for example, that consent cannot be inferred by certain circumstances such as the victim's words or conduct under coercive circumstances, or the victim's silence or lack of resistance. ${ }^{33}$ Furthermore, credibility, character, or predisposition to sexual availability cannot be inferred by the sexual nature of a victim's prior or subsequent conduct. ${ }^{34}$ Evidence of the prior or subsequent sexual conduct of a victim or witness shall generally not be admitted. ${ }^{35}$ Article $68(1)$ of the ICC Statute also provides for the protection of victims and witnesses with specific regard to gender and gender violence.

The Statute further obligates the Prosecutor to appoint advisers with expertise on sexual and gender violence pursuant to Article 42(9) and to consider the gender of victims and witnesses as well as the nature of sexual and gender crimes in investigations pursuant to Article 54(1)(b). Concerning the judiciary, Article 36(8) calls upon the States Parties to appoint judges with expertise on violence against women and children. Furthermore, the Rules of Procedure and Evidence require organs of the Court to take gender-sensitive measures with respect to victims and witnesses $^{36}$ and to provide training on issues of sexual violence and gender sensitivity. ${ }^{37}$

A further significant development, and a novelty in international criminal law, ${ }^{38}$ is the inclusion of the term "gender" in the ICC Statute. Article 21(3) provides that the application and interpretation of the law must be without adverse distinction founded on grounds of gender, among others. This can be considered as the most wide-reaching and thus significant gender provision in

\footnotetext{
${ }^{29}$ See also Andrea Raab \& Siobhan Hobbs, Forced Relationships: Prosecutorial Discretion as a Pathway to Survivor-Centric Justice, OPINIO JURIS (Sept. 13, 2018), http://opiniojuris.org/2018/09/13/forced-relationships-prosecutorial-discretion-as-apathway-to-survivor-centric-justice/.

${ }^{30}$ On reparations, see Ruth Rubio-Marín, Reparations for Conflict-Related Sexual and Reproductive Violence: A Decalogue, 19 WM. \& MARY J. WOMEN \& L. 69, 85 (2012).

${ }^{31}$ ICC Elements of Crimes art. 7(1)(g)-1, no. 1, n. 15; art. 8(2)(b)(xxii)-1, no. 1, n. 50; art. 8(2)(e)(vi)-1, no. 1, n. 63, https:// www.icc-cpi.int/Publications/Elements-of-Crimes.pdf.

${ }^{32} I d$. at art. 6(b), no. 1, n. 3. The proposed African Criminal Court's Statute would be the first international instrument to explicitly list "acts of rape or any other form of sexual violence" as genocidal acts in art. 28B(f), see Kai Ambos, supra note 25, at $39-40$.

${ }^{33}$ Rules of Procedure and Evidence of the International Criminal Court, Rule 70(a)-(c), https://www.icc-cpi.int/ Publications/Rules-of-Procedure-and-Evidence.pdf.

${ }^{34} I d$. at Rule $70(\mathrm{~d})$.

${ }^{35} I d$. at Rule 71 .

${ }^{36}$ See, e.g., id. at Rules 16(1)(d), 17(2)(b)(iii), 72, 86, 88(1), 88(5), 112(4).

${ }^{37} I d$. at Rules $17(2)(\mathrm{a})(\mathrm{iv}), 18(\mathrm{~d})$.

${ }^{38}$ See GreY, supra note 22, at 113; Valerie Oosterveld, The Definition of "Gender" in the Rome Statute of the International Criminal Court: A Step Forward or Back for International Criminal Justice?, 18 HARV. HuM. RTS. J. 55 (2005); SCHWARZ, supra note 6 , at 38 .
} 
the ICC framework because it generally prohibits gender discrimination. ${ }^{39}$ In Article 7(3), gender is defined as referring "to the two sexes, male and female, within the context of society. The term 'gender' does not indicate any meaning different from the above." This circular ${ }^{40}$ and ambiguous definition resulted from controversial negotiations, during which some delegations feared that "gender" would also relate to sexual orientation. ${ }^{41}$ The definition elicited criticism, ${ }^{42}$ particularly due to its reference to "the two sexes," which reproduces a heteronormative and exclusionary conceptualization of sex as a biological binary. ${ }^{43}$ These concerns have recently led the International Law Commission to remove the definition from the draft articles on prevention and punishment of crimes against humanity, which otherwise closely follow Article 7 of the ICC Statute. ${ }^{44}$ Nevertheless, by referring to the "context of society," the ICC Statute acknowledges that gender and sex are not synonymous and allows for, or indeed requires, ${ }^{45}$ an understanding of gender as a social construct instead of a presumed biological reality. ${ }^{46}$ The provision may thus contribute to a nuanced understanding of the terms "sex" and "gender" in international law and to a gendersensitive interpretation of crimes under international law.

\section{Great Disillusions: Early ICC Practice on Sexual Violence}

Against the background of its progressive legal framework, the ICC's practice concerning the prosecution of sexual crimes is undoubtedly disappointing. ${ }^{47}$ Almost two decades after its establishment, with one conviction overturned on appeal ${ }^{48}$ and another one currently subject to appeal, ${ }^{49}$ the ICC stands with only a single final conviction for sexual crimes. ${ }^{50}$ Although an international court's success cannot, and should not, be measured simply by its number of convictions, ${ }^{51}$ it is

\footnotetext{
${ }^{39}$ Altunjan, supra note 1, at 56-57. See Barbara Bedont, Gender-Specific Provisions in the Statute of the International Criminal Court, in 1 Essays on the Rome Statute of the International Criminal Court 183, 185 (Flavia Lattanzi \& William A. Schabas eds., 1999); Margaret M. deGuzman, in Rome STATUTE of THE InTERnAtional CriminAL CourT: A Commentary, Article 21 margin nos 49-52 (Otto Triffterer \& Kai Ambos eds., 3d ed. 2016).

${ }^{40}$ See KAPPLER, supra note 20, at 172.

${ }^{41}$ See Louise A. Chappell, The Politics of Gender Justice at the International Criminal Court: Legacies and Legitimacy 44-46 (2016); Marlies Glasius, The International Criminal Court: A Global Civil Society ACHIEVEMENT 86-87 (2006); GREY, supra note 22, at 40-42; Oosterveld, supra note 38, at 58-66; SCHWARZ, supra note 6 , at 38-39.

${ }^{42}$ See Oosterveld, supra note 38, at 71-81 with further references. See also Global Justice Center, Submission to the International Law Commission: The Need to Integrate a Gender-Perspective into the Draft Convention on Crimes Against Humanity, at 11-14 (Nov. 30, 2018), https://www.globaljusticecenter.net/blog/19-publications/1011-submission-to-theinternational-law-commission-the-need-to-integrate-a-gender-perspective-into-the-draft-convention-on-crimes-againsthumanity.

${ }^{43}$ See KAPPLER, supra note 20, at 159-60; SCHWARZ, supra note 6, at 40.

${ }^{44}$ Int'l Law Comm'n, Rep. on Its Seventy-First Session, U.N. Doc. A/74/10, at 45-46 (2019). See also Global Justice Center, supra note 42, at 11-14. On these developments, see generally Grey et al., supra note 20, at 959-61.

${ }^{45}$ Grey et al., supra note 20 , at 961 .

${ }^{46}$ See Bedont, supra note 39, at 187; KAPPLER, supra note 20, at 160-69; SCHWARZ, supra note 6, at 39-40. See especially Oosterveld, supra note 38 , at 82 , pointing out and criticizing the "constructive ambiguity" of the gender definition. See also Valerie Oosterveld, Constructive Ambiguity and the Meaning of "Gender" for the International Criminal Court, 16 INT'L FEMinist J. POL. 563 (2014).

${ }^{47}$ For an overview on the relevant decisions, see ALtUNJAN, supra note 1, at 58-60. See also CHAPPELL, supra note 41, at 104-106; Schwarz, supra note 6, at 24; Leonie Steinl, Of Rhetoric and Reality: The Nobel Peace Prize and Conflict-Related Sexualized Violence, Verfassungsblog (Dec. 10, 2018), https://verfassungsblog.de/of-rhetoric-and-reality-the-nobel-peaceprize-and-conflict-related-sexualized-violence/.

${ }^{48}$ ICC, Prosecutor v. Bemba, ICC-01/05-01/08 A, Appeals Judgment (Jun. 8, 2018), https://www.icc-cpi.int/CourtRecords/ CR2018_02984.PDF.

${ }^{49}$ ICC, Prosecutor v. Ongwen, ICC-02/04-01/15, Judgment (Feb. 4, 2021), https://www.icc-cpi.int/CourtRecords/CR2021_ 01026.PDF.

${ }^{50}$ Ntaganda Judgment, ICC-01/04-02/06; Ntaganda Appeals Judgment, ICC-01/04-02/06 A A2.

${ }^{51}$ On "success" in prosecuting gender-based crimes, see GREY, supra note 22 , at 30-36.
} 
evident that the ICC has not fulfilled the objective of ending impunity for gender crimes under international criminal law as hoped by Richard Goldstone and other observers.

Sexual violence charges in cases before the ICC have failed for various reasons at all stages of the proceedings. Evidently, not all counts originally investigated and charged in criminal trials will result in convictions that are upheld on appeal. Nevertheless, a review of the ICC's cases indicates some specificities in relation to sexual crimes. ${ }^{52}$ Based on exemplary cases, the following section explores how and why sexual violence charges have failed.

\section{Lack of Prioritization of Sexual Violence Investigations}

The first trial before the ICC, in the case against Thomas Lubanga Dyilo, solely concerned the charge of enlistment, conscription, and use of child soldiers. ${ }^{53}$ Early on in the investigation, the prosecution had reportedly obtained evidence of sexual violence, but it did not deem such acts to be of a sufficiently systematic nature to meet the crimes against humanity threshold and therefore suspended investigations on the matter. ${ }^{54}$ After failing to properly investigate and bring charges in the first place, the former Prosecutor Luis Moreno Ocampo then refused to request an amendment to the charges at a later stage of the proceedings after more evidence had emerged. ${ }^{55}$ This prosecutorial approach was criticized, ${ }^{56}$ not least by the judges themselves, stating that " $[\mathrm{t}]$ he Chamber strongly deprecates the attitude of the former Prosecutor in relation to the issue of sexual violence." 57

While several charges of sexual crimes were brought by the Prosecutor in the case against Callixte Mbarushimana, the Pre-Trial Chamber refused to confirm them. ${ }^{58}$ In the original arrest warrant application, it was alleged that Mbarushimana had committed the crime of gender-based persecution, ${ }^{59}$ which constituted a historical first in international criminal law. Yet the evidence brought by the prosecution to tie the accused to the conduct in question relied solely on indirect documentation; ${ }^{60}$ it was deemed too weak to confirm any of the charges. ${ }^{61}$

The failure of the Lubanga and Mbarushimana cases with respect to sexual violence demonstrates that a consideration of the gendered dimensions of international crimes is imperative from the outset of investigations. If the collection of evidence concerning sexual violence is not prioritized, cases are likely to fail at an early stage of the proceedings. In this regard, it is important that

\footnotetext{
${ }^{52}$ See CHAPpell, supra note 41, at 108.

${ }^{53}$ ICC, Prosecutor v. Lubanga, ICC-01/04-01/06, Judgment (Mar. 14, 2012), https://www.icc-cpi.int/CourtRecords/ CR2012_03942.PDF; ICC, Prosecutor v. Lubanga, ICC-01/04-01/06 A 5, Appeals Judgment (Dec. 1, 2014), https://www. icc-cpi.int/CourtRecords/CR2014_09844.PDF.

${ }^{54}$ See Chappell, supra note 41, at 111; GReY, supra note 22, at 130-31; Niamh Hayes, Sisyphus Wept: Sexual Violence at the International Criminal Court, in The Ashgate Research Companion to International Criminal Law: Critical Perspectives 7, 11 (Yvonne McDermott et al. eds., 2016).

${ }^{55}$ ICC, Prosecutor v. Lubanga, ICC-01/04-01/06, Prosecutor's Information on Further Investigation, para. 7 (Jun. 28, 2006), https://www.icc-cpi.int/CourtRecords/CR2006_02549.PDF. See also ICC, Prosecutor v. Lubanga, ICC-01/04-01/06, Prosecution's Further Observations Regarding the Legal Representatives' Joint Request Made Pursuant to Regulation 55 (Jun. 12, 2009), https://www.icc-cpi.int/CourtRecords/CR2009_04507.PDF (opposing the victims' counsel application for re-characterization of the charges during trial).

${ }^{56}$ See generally CHAPPELL, supra note 41, at 110-14; GREY, supra note 22, at 128-42. Besides sexual violence, the trial also produced evidence of reproductive violence in the form of forced abortions, which was not part of the charges and thus did not appear in the judgment, see ICC, Prosecutor v. Lubanga, ICC-01/04-01/06 A 5, Transcript T-150, at 35-36 (Mar. 18, 2009), https://www.legal-tools.org/doc/1baca0/pdf; see also GREY, supra note 22, at 136.

${ }^{57}$ ICC, Prosecutor v. Lubanga, ICC-01/04-01/06, Sentencing Decision, para. 60 (Jul. 10, 2012), https://www.icc-cpi.int/ CourtRecords/CR2012_07409.PDF.

${ }^{58}$ ICC, Prosecutor v. Mbarushimana, ICC-01/04-01/10, Decision on the Confirmation of Charges (Dec. 16, 2011), https:// www.icc-cpi.int/CourtRecords/CR2011_22538.PDF.

${ }^{59}$ ICC, Situation in the Democratic Republic of the Congo, ICC-01/04, Prosecution's Application Under Article 58, at 17 (Aug. 20, 2010), https://www.icc-cpi.int/CourtRecords/CR2011_01367.PDF.

${ }^{60}$ Hayes, supra note 54 , at 28.

${ }^{61}$ See CHAPPELL, supra note 41, at 122; GREY, supra note 22, at 164-65.
} 
investigators not only receive proper resources, but also trainings on gender sensitivity. The effects of sexual violence are often less visible than those of other crimes. Additionally, many survivors of sexual violence are reluctant to share their experiences due to the stigmatization they often suffer. In questioning witnesses, it is therefore crucial that investigators act with sensitivity towards cultural issues, gender roles, and the power dynamics at play in the individual situation. More generally, investigations must be conducted with an understanding of the impact of sexual violence on survivors and their communities.

\section{Double Standards? The Challenges of Building Strong Sexual Violence Cases}

The case against Germain Katanga was the first ICC trial to explicitly deal with sexual crimes. The confirmed charges included rape and sexual slavery committed in connection with an attack on the village of Bogoro. ${ }^{62}$ Katanga was convicted on a majority of the charges, but acquitted of all sexual crimes. The Trial Chamber found that although sexual violence had been committed by militia members, it did not form part of the common purpose of the group under Article 25(3)(d) of the ICC Statute. ${ }^{63}$ The distinction drawn by the judges between sexual violence and other types of violence such as pillaging indicates that sexual crimes may have been held to a higher standard than other crimes. ${ }^{64}$

The ICC secured its first conviction for sexual crimes against Jean-Pierre Bemba Gombo in 2016. ${ }^{65}$ Among other counts, he was found guilty of rape as a crime against humanity and a war crime. The Appeals Chamber, however, overturned this decision and acquitted Bemba of all charges. ${ }^{66}$ Although the reasons for the acquittal did not specifically relate to the charges of sexual violence, the consequences of the majority judgment are likely to disproportionally affect future prosecutions of sexual crimes. In establishing stricter requirements for the specificity of charges brought at the confirmation level ${ }^{67}$ and limiting the possibility to add underlying acts at a later stage, ${ }^{68}$ the majority judgment forces the prosecution to present a complete picture of the relevant conduct and evidence at the outset of proceedings. With respect to sexual violence, it has often been observed that evidence is uncovered at a relatively late stage, ${ }^{69}$ likely due to lack of investigative prioritization as well as survivors' reluctance to testify. The Bemba appeals judgment effectively prevents the Prosecutor from responding to the emergence of new evidence during a trial in such cases. ${ }^{70}$ Furthermore, the stricter standard introduced by the majority judgment with regard to command responsibility and the measures required of remote commanders will make prosecution of sexual crimes significantly more difficult. ${ }^{71}$ In the typical absence of clear orders to

\footnotetext{
${ }^{62}$ ICC, Prosecutor v. Katanga and Chui, ICC-01/04-01/07, Decision on the Confirmation of Charges, paras. 339-54 (Sep. 30, 2008), https://www.icc-cpi.int/CourtRecords/CR2008_05172.PDF.

${ }^{63}$ ICC, Prosecutor v. Katanga, ICC-01/04-01/07, Judgment, paras. 1663-64 (Mar. 7, 2014), https://www.icc-cpi.int/ CourtRecords/CR2015_04025.PDF.

${ }^{64}$ See GreY, supra note 22, at 272; Carsten Stahn, Justice Delivered or Justice Denied?: The Legacy of the Katanga Judgment, 12 J. INT'L CRIM. Just. 809, 821 (2014).

${ }^{65}$ ICC, Prosecutor v. Bemba, ICC-01/05-01/08, Judgment (Mar. 21, 2016), https://www.icc-cpi.int/CourtRecords/CR2016 02238.PDF.

${ }^{66}$ Bemba Appeals Judgment, ICC-01/05-01/08 A.

${ }^{67}$ Id. at para. 110 .

${ }^{68} \mathrm{Id}$. at para. 115.

${ }^{69}$ See Sarah Hibbert, The Bemba Acquittal: A Blow to the ICC's Legitimacy in a Time of Crisis, 34 TEMP. INT'L \& COMP. L. J. 95, 118 (2019).

${ }^{70}$ See Joseph Powderly, Introductory Note to Prosecutor v. Jean-Pierre Bemba Gombo: Judgment on the Appeal of Mr. JeanPierre Bemba Gombo against Trial Chamber III's “Judgment Pursuant to Article 74 of the Statute” (Int'l Crim. Ct.), 57 INT'L Legal Materials 1031, 1032 (2018).

${ }^{71}$ Bemba Appeals Judgment, ICC-01/05-01/08 A, at paras. 166-94. See Hibbert, supra note 69, at 118; Ray Murphy, Command Responsibility After Bemba, in N.Z. Y.B. INT'L L. 94, 118 (Christian Riffel \& Róisín Burke eds., 2019); Susana SáCouto \& Patricia Viseur Sellers, The Bemba Appeals Judgment: Impunity for Sexual and Gender-Based Crimes?, 27 WM \& MARY BiLl RTS. J. 599 (2019).
} 
commit sexual violence, there is often a reluctance to hold leaders accountable for such crimes committed by their subordinates. ${ }^{72}$ As evidenced by the partial acquittal of Katanga in the context of common purpose liability, sexual violence is more likely to be regarded as an excess than other types of crimes, and will thus be particularly vulnerable to this stricter construction of command responsibility.

\section{Conceptual Mis-Understandings of Sexual Violence}

In 2008, the Office of the Prosecutor applied for an arrest warrant against Bemba, alleging that, among other crimes, female combatants under Bemba's command had forced male civilians to undress in two instances. ${ }^{73}$ The Pre-Trial Chamber, however, held that this conduct did not meet the gravity threshold required for the crime against humanity of any other form of sexual violence of comparable gravity. ${ }^{74}$ This finding, for which the judges did not give any reasons, is questionable because forced nudity had previously been categorized as a crime of sexual violence by the ICTR in its 1998 Akayesu judgment. ${ }^{75}$ Furthermore, the drafters of the ICC Statute had intended the crime of sexual violence to apply to forced nudity. ${ }^{76}$ Against this background and in the absence of any previous ICC jurisprudence on this issue, the dismissal of the charge would have required a more thorough analysis and an identification of the criteria to be used for the gravity assessment.

In the case against Uhuru Muigai Kenyatta and Francis Kirimi Muthaura, a variety of charges including the crime of rape was confirmed by the Pre-Trial Chamber. With regard to the conduct of forced circumcision and penile amputation, however, the judges refused to confirm the charge of sexual violence. They asserted that such acts were not sexual in nature, but instead motivated by ethnic prejudice and the desire to demonstrate cultural superiority. ${ }^{77}$ The Pre-Trial Chamber thus defined these acts as the crime against humanity of other inhumane acts, ${ }^{78}$ which elicited heavy criticism in the literature. ${ }^{79}$ Indeed, the conceptualization of sexual violence underlying the PreTrial Chamber's decision is extremely restrictive and fails to take into account the principle of intersectionality as the basis for selective targeting of specific victims. In many cases, sexual violence is employed precisely as a tool of asserting cultural superiority in conflict scenarios with

\footnotetext{
${ }^{72}$ See Kelly Dawn Askin, Holding Leaders Accountable in the International Criminal Court (ICC) for Gender Crimes Committed in Darfur, 1 Genocide Stud. \& Prevention 13, 24 (2006).

${ }^{73}$ ICC, Situation in the Central African Republic, ICC-01/05, Prosecutor's Submission on Further Information and Materials, at 8 (May 27, 2008).

${ }^{74}$ ICC, Prosecutor v. Bemba, ICC-01/05-01/08, Arrest Warrant Decision, paras. 39-40 (Jun. 10, 2008), https://www.icc-cpi. int/CourtRecords/CR2008_04180.PDF. The Prosecutor later dropped the separate charge of forced nudity as sexual violence, but presented the respective evidence again under the charge of outrages upon personal dignity (art. 8(2)(c)(ii) of the ICC Statute) at the confirmation hearings. The Pre-Trial Chamber did not confirm this charge, effectively eliminating the act of forced nudity from the Bemba case, see ICC, Prosecutor v. Bemba, ICC-01/05-01/08, Decision on the Confirmation of Charges, para. 310 (Jun. 15, 2009), https://www.icc-cpi.int/CourtRecords/CR2009_04528.PDF.

${ }^{75}$ Akayesu Judgment, Case No. ICTR-96-4-T, at para. 688 ("The incident described by Witness KK in which the Accused ordered the Interahamwe to undress a student and force her to do gymnastics naked in the public courtyard of the bureau communal, in front of a crowd, constitutes sexual violence.").

${ }^{76}$ See Valerie Oosterveld, Gender-Sensitive Justice and the International Criminal Tribunal for Rwanda: Lessons Learned for the International Criminal Court, 12 New ENG. J. INT'L \& Compar. L. 119, 124 (2005).

${ }^{77}$ ICC, Prosecutor v. Kenyatta et al., ICC-01/09-02/11, Decision on the Confirmation of Charges, para. 266 (Jan. 23, 2012), https://www.icc-cpi.int/CourtRecords/CR2012_01006.PDF. See also para. 265 ("[N]ot every act of violence which targets parts of the body commonly associated with sexuality should be considered an act of sexual violence.”). See ALTUNJAN, supra note 1 , at 285 .

${ }^{78} I d$. at para. 270.

${ }^{79}$ See, e.g., Rosemary Grey, Conflicting Interpretations of 'Sexual Violence' in the International Criminal Court, 29 Australian Feminist Stud. 273, 282-283 (2014); Grey, supra note 22, at 292-94; Christopher K. Hall, Joseph Powderly, \& Niamh Hayes, in Rome Statute of the International Criminal Court: A Commentary, Article 7 margin no. 68 (Otto Triffterer \& Kai Ambos eds., 3d ed. 2016); Hayes, supra note 54, at 41-42; SCHWARZ, supra note 6, at 321-22.
} 
ethnic dimensions. Against this background, the Chamber's apparent assumption that sexual violence and ethnically motivated violence are mutually exclusive is implausible. On a related note, the Prosecutor-for unknown reasons - chose not to charge the conduct of penile amputation specifically as the crime of enforced sterilization. ${ }^{80}$ In the absence of enforced sterilization charges, the aspect of loss of reproductive capacity did not feature in the ensuing trial, effectively rendering the reproductive component of the criminal conduct invisible.

Both of these decisions illustrate a more general problem: A clear understanding of what constitutes a crime of sexual violence under international criminal law has not yet been established. This will be further discussed in the last section of this Article.

\section{Bridging the Gap: Progressive Approaches to Sexual Violence at the ICC}

Despite the setbacks outlined in the previous section, the ICC has made significant progress in prosecuting sexual violence in its more recent practice. ${ }^{81}$ At the pre-trial level, sixteen out of the twenty-six cases brought before the ICC as of 2018 included charges of sexual violence, ${ }^{82}$ indicating that such crimes are no longer sidelined in the investigative stage. Concerning judicial approaches to sexual violence, two recent judgments prominently illustrate progress in the ICC's practice: The court recently procured its first final conviction for sexual crimes in the case against Bosco Ntaganda. ${ }^{83}$ Furthermore, it convicted Dominic Ongwen for the crimes of rape, sexual slavery, forced pregnancy, and forced marriage as another inhumane act. ${ }^{84}$ In these judgments and other current cases, it can be observed that innovative and gender-sensitive interpretations of sexual crimes are being put forward, which indicates that the outdated conceptualizations of sexual violence visible in the ICC's early practice have been overcome. The following section highlights the recent progressive developments and identifies persisting challenges.

\section{Prosecutorial Strategies}

Under the term of its second Prosecutor, Fatou Bensouda, many of the problems surrounding earlier ICC investigations and prosecutions have been remedied. Concerning sexual violence in particular, the Office of the Prosecutor made important progress by adopting the Policy Paper on Sexual and Gender-Based Crimes in 2014, which elaborates on measures aimed at conducting gender-sensitive investigations and prosecutions. ${ }^{85}$

The adoption of the Policy Paper has been labelled a "potentially game-changing" step towards more gender justice at the ICC. The Policy Paper outlines a broad understanding of gender, emphasizing the "social construction of gender, and the accompanying roles, behaviours, activities, and attributes assigned to women and men, and to girls and boys." ${ }^{77}$ In acknowledging this socially constructed nature of gender, the Policy Paper provides welcome clarity relating to the

\footnotetext{
${ }^{80}$ See Michael Cottier \& Sabine Mzee, in Rome Statute of the International Criminal Court: A Commentary, Article 8 margin no. 737 (Otto Triffterer \& Kai Ambos eds., 3d ed. 2016).

${ }^{81}$ For an overview on ICC cases dealing with sexual and gender-based violence, see GREY, supra note 22 , at $123-246$.

${ }^{82}$ Women's Initiatives for Gender Justice, Gender Report Card on the International Criminal Court, at 42 (2018), https:// 4genderjustice.org/ftp-files/publications/Gender-Report_design-full-WEB.pdf.

${ }^{83}$ Ntaganda Appeals Judgment, ICC-01/04-02/06 A A2.

${ }^{84}$ Ongwen Judgment, ICC-02/04-01/15.

${ }^{85}$ The Office of the Prosecutor of the International Criminal Court, Policy Paper on Sexual and Gender-Based Crimes (2014), https://www.icc-cpi.int/iccdocs/otp/otp-Policy-Paper-on-Sexual-and-Gender-Based-Crimes-June-2014.pdf. See also Chappell, supra note 41, at 124-26; Valerie Oosterveld, The ICC Policy Paper on Sexual and Gender-Based Crimes: A Crucial Step for International Criminal Law, 24 WM \& MARY J. RACE, GENDER, AND Soc. J. 443, 453-56 (2018).

${ }^{86}$ Oosterveld, supra note 85 , at 457.

${ }^{87}$ The Office of the Prosecutor of the International Criminal Court, supra note 85, at 3.
} 
ambiguous gender definition in Article 7(3) of the ICC Statute. ${ }^{88}$ Further, the Policy Paper is guided by the progressive understanding that gender-based crimes are not limited to sexual violence, and that both sexual and gender-based crimes are not limited to women. ${ }^{89}$ It also acknowledges that gender intersects with other identity factors such as race and sexual orientation, ${ }^{90}$ which is a hopeful sign towards the institutionalization of critical and antidiscriminatory approaches to the prosecution of international crimes at the ICC.

With regard to charging strategies, the Prosecutor voiced her intention to charge sexual and gender-based crimes as different categories of crimes-genocide, crimes against humanity, and war crimes -in order to capture the different context and nature of their commission..$^{91}$ Further, she outlined that such charges would be brought cumulatively "in order to reflect the severity and multifaceted character of these crimes fairly", both "explicitly as crimes per se" and "as forms of other violence", for example rape as torture. ${ }^{92}$ In manifesting that sexual and gender-based crimes are to be afforded the highest priority during investigations and prosecutions, the Policy Paper has already had a noticeable influence on the ICC's recent practice, as reflected, for example, in the broad scope of gender-based charges brought against Ongwen.

\section{Recent ICC Practice}

1. New Victims: Sexual Violence Against Men and Intra-Party Sexual Violence

Several recent ICC decisions and cases paint a hopeful picture towards a more inclusive interpretation of sexual crimes. In the history of international law, sexual and gender-based violence has often been conflated with violence against women. The ICC appears to have overcome this problematic notion in two recent cases. Both the convictions of Bemba and Ntaganda included the rape of male victims, with both Trial Chambers explicitly clarifying that the crime of rape under the ICC Statute is gender-neutral. ${ }^{93}$ Given the problematic categorization of genital mutilations of men in the Kenyatta case as discussed above, as well as the exclusion of evidence on sexual violence against men in the Ongwen trial, ${ }^{94}$ the Bemba and Ntaganda cases are likely to serve as important precedents.

The case against Ntaganda is also significant with regard to the treatment of intra-party sexual violence as war crimes. Among other crimes, the Trial Chamber convicted Ntaganda for rape and sexual slavery of forcibly recruited child soldiers as war crimes. ${ }^{95}$ The Appeals Chamber had previously decided that the ICC Statute does not exclude members of an armed group from protection against acts committed by members of the same armed group. ${ }^{96}$ Although the decision has been criticized for its the apparent detachment of international criminal law from international

\footnotetext{
${ }^{88}$ Oosterveld, supra note 85 , at $450-52$.

${ }^{89}$ The Office of the Prosecutor of the International Criminal Court, supra note 85, at 3 ("[Gender-based crimes] may include non-sexual attacks on women and girls, and men and boys, because of their gender.").

${ }^{90} \mathrm{Id}$. at para. 27. On intersectionality, see generally Kimberle Crenshaw, Demarginalizing the Intersection of Race and Sex: A Black Feminist Critique of Antidiscrimination Doctrine, Feminist Theory and Antiracist Politics, UnIV. CHI. LEGAL F. 139 (1989).

${ }^{91}$ The Office of the Prosecutor of the International Criminal Court, supra note 85, para. 73. See AltunJAN, supra note 1, at 60.

${ }^{92} I d$. at para. 72 .

${ }^{93}$ Bemba Judgment, ICC-01/05-01/08, at paras. 100, 494, 633-34; Ntaganda Judgment, ICC-01/04-02/06, at paras. 933, $940-42$.

${ }^{94} \mathrm{GREY}$, supra note 22 , at $257-58$.

${ }^{95}$ Ntaganda Judgment, ICC-01/04-02/06, at paras. 964-86.

${ }^{96}$ ICC, Prosecutor v. Ntaganda, ICC-01/04-02/06 OA5, Judgment on the Appeal of Mr Ntaganda Against the "Second Decision on the Defence's Challenge to the Jurisdiction of the Court in Respect of Counts 6 and 9" (Jun. 15, 2017), https://www.icc-cpi.int/CourtRecords/CR2017_03920.PDF.
} 
humanitarian law, ${ }^{97}$ its practical implications for victims of sexual violence are groundbreaking. The approach put forward by the Appeals Chamber unequivocally allows for the prosecution of intra-party sexual violence as war crimes, and thus closes an accountability gap in international criminal law. ${ }^{98}$

\section{New Crimes: Forced Pregnancy and Gender-Based Persecution}

Out of the seven sexual and gender-based crimes against humanity and war crimes enumerated in the ICC Statute-rape, sexual slavery, enforced prostitution, forced pregnancy, enforced sterilization, any other form of sexual violence, and gender-based persecution-five have now been charged at the ICC. Two recent cases are particularly noteworthy. The judgment against former Lord's Resistance Army commander Dominic Ongwen contains the first conviction of the crime against humanity and war crime of forced pregnancy, a novelty of the ICC Statute. ${ }^{99}$ In light of the broad nature of sexual and gender-based charges and resulting convictions, the Ongwen case has been deemed one of the most innovative ICC cases to date in this regard. ${ }^{100} \mathrm{~A}$ further promising development is the trial against Al Hassan Ag Abdoul Aziz, which opened in July 2020 and involves the crime of gender-based persecution. ${ }^{101}$ After this charge was withdrawn at pre-trial level in the Mbarushimana case, this will be the ICC's first opportunity to address this crime. ${ }^{102}$ There is no precedent for the prosecution of forced pregnancy and gender-based persecution in international criminal law, meaning that both prosecutors and judges may be unfamiliar with the nature and definition of the crimes, and their application will likely require more effort and explanatory arguments. These developments thus illustrate a welcome willingness on the part of prosecutors and judges to explore new territory and to take advantage of the full potential of the ICC Statute with regard to sexual and gender-based crimes.

The two cases are also significant in their own right. With regard to forced pregnancy, the Ongwen case constitutes the first explicit prosecution of a reproductive crime in the recent history of international criminal law. While some international trials after World War II did include explicit charges or at least underlying evidence of enforced sterilization and forced abortion, ${ }^{103}$ such crimes had not been prosecuted without a nexus to genocide or ethnicity-related scenarios. A shift in this paradigm was brought about by reports from the former Yugoslavia in the mid1990s, which referred to a deliberate strategy of impregnating women and detaining them until they were unable to terminate the pregnancy, thus forcing them to give birth to children presumed to belong to the perpetrator's ethnic group. ${ }^{104}$ Against this background, the crime of forced pregnancy was included in the ICC Statute on the initiative of the Women's Caucus for Gender Justice; perhaps even more significantly, its definition was expanded beyond the narrow ethnicity-related

\footnotetext{
${ }^{97}$ See Kevin Jon Heller, ICC Appeals Chamber Says A War Crime Does Not Have to Violate IHL, OpINIO JURIS (Jun. 15, 2017), http://opiniojuris.org/2017/06/15/icc-appeals-chamber-holds-a-war-crime-does-not-have-to-violate-ihl/; Cóman Kenny \& Yvonne McDermott, The Expanding Protection of Members of a Party's Own Armed Forces Under International Criminal Law, 68 INT'L \& COMPAR. L. QUARTERly 943, 945-60 (2019).

${ }^{98}$ AltunJAN, supra note 1, at 59. See also Joanna Frivet, Expanding IHL Through ICL: How Prosecutorial Opportunism and Judicial Activism Redefined Intra-Party SGBV Crimes at the ICC, 2 HumANITÄres VÖLKERRECHT 53, 64-66 (2019); GreY, supra note 22, at 274-278; Marco Longobardo, The Criminalisation of Intra-Party Offences in Light of Some Recent ICC Decisions on Children in Armed Conflict, 19 INT'L CrIM. L. REV. 600 (2019).

${ }^{99}$ Ongwen Judgment, ICC-02/04-01/15, at paras. 2717-22.

${ }^{100}$ See GREY, supra note 22, at 171.

${ }^{101}$ ICC, Prosecutor v. Al Hassan, ICC-01/12-01/18, Decision on the Confirmation of the Charges, Count 13 (Sep. 30, 2019).

${ }^{102}$ See Grey et al., supra note 20, at 975-77; GREY, supra note 22, at 278-83. See also Christopher K. Hall et al., supra note 79, Article 7 margin no. 83; KAPPLER, supra note 20, at 137-40.

${ }^{103}$ Most notably, see United States v. Greifelt et al. (RuSHA Case), Judgment (Mar. 10, 1948), 5 Trials Of WAR CrIMINALS Before the Nuernberg Military Tribunals 88 (United States Government Printing Office 1948).

${ }^{104}$ Final Rep. of the Comm'n of Experts, Annex to U.N. Doc. S/1994/674, para. 248 (1994).
} 
context of the Yugoslavia precedent. ${ }^{105}$ The Trial Chamber explicitly clarified in the Ongwen judgment that the crime of forced pregnancy protects the value of reproductive autonomy. ${ }^{106}$ This indicates a clear understanding of the conceptual differences between sexual and reproductive violence. ${ }^{107}$

Concerning the Al Hassan case, it is noteworthy that the crime of persecution is charged on intersecting religious and gender grounds, which constitutes important progress concerning the practical application of the principle of intersectionality within the ICC framework. ${ }^{108}$ Besides this trial, gender-based persecution is also part of the Afghanistan investigation ${ }^{109}$ and the Nigeria preliminary examination. ${ }^{10}$ In the latter case, it is particularly significant that the examination is not limited to crimes against women; instead, the Prosecutor is also investigating the persecution of men and boys who are reportedly being forced to participate in hostilities by Boko Haram or targeted by the Nigerian security forces for suspected membership in Boko Haram. This illustrates that the Office of the Prosecutor understands the broad nature of gendered harms, which reach far beyond sexual violence and may affect persons of all genders.

To date, the only sexual and gender-based crimes which have not been charged at the ICC are enforced prostitution and enforced sterilization. Curiously, prosecutions of these crimes trace back to the early stages of international criminal law. Enforced prostitution was already included among the list of war crimes drawn up by the United Nations War Crimes Commission in 1943, which served as a basis for trials in national and military jurisdictions in Asia and Europe. ${ }^{111}$ Several of the post-World War II trials also dealt with enforced sterilization, most notably the so-called Medical Case. ${ }^{112}$ Nevertheless, the crimes of enforced prostitution and enforced sterilization have played no role in the practice of any of the courts established since the 1990s. With regard to enforced prostitution, the lack of ICC practice may be explained in relation to the similar crime of sexual slavery, which prosecutors appear to prefer to charge. Despite the similarities, however, the elements of the crimes are not congruent and the additional pecuniary element of enforced prostitution ${ }^{113}$ should be made visible. ${ }^{114}$ Concerning enforced sterilization, this crime may apply to both targeted sterilization campaigns, as documented for example in Peru under Fujimori, ${ }^{115}$ as well as to genital mutilations. The latter acts may also be categorized as any other form of sexual violence, as mentioned above with regard to the Kenyatta case. Yet such an

\footnotetext{
${ }^{105}$ See also Grey, supra note 26, at 921-922; Dorean M. Koenig \& Kelly D. Askin, International Criminal Law and The International Criminal Court Statute: Crimes Against Women, in 2 WOMEN AND INTERNATIONAL HumAN Rights LAW 3 , 15 (Kelly D. Askin \& Dorean M. Koenig eds., 2000).

${ }^{106}$ Ongwen Judgment, ICC-02/04-01/15, at para. 2717.

${ }^{107}$ See Altunjan, supra note 1, at 97-99, 220-24.

${ }^{108}$ See also Grey et al., supra note 20 , at 977.

${ }^{109}$ ICC, Situation in the Islamic Republic of Afghanistan, ICC-02/17, Prosecutor's Request for Authorisation of an Investigation, para. 115-21 (Nov. 20, 2017), https://www.icc-cpi.int/CourtRecords/CR2017_06891.PDF.

${ }^{110}$ The Office of the Prosecutor of the International Criminal Court, Report on Preliminary Examination Activities 2019, paras. 186-87 (2019), https://www.icc-cpi.int/itemsDocuments/191205-rep-otp-PE.pdf.

${ }^{111}$ United Nations War Crimes Comm'n, Rep. of the Sub-Committee as Adopted on 2nd December, 1943 (1943), https:// www.legal-tools.org/en/doc/4cb3b4/. See also Dan Plesch, Susana SáCouto, \& Chante Lasco, The Relevance of the United Nations War Crimes Commission to the Prosecution of Sexual and Gender-Based Crimes Today, 25 CRIM. L. F. 349 (2014) with further references to specific trials.

${ }^{112}$ United States v. Brandt et al. (Medical Case), Judgment (Jul. 19, 1947), 2 Trials of War Criminals Before the Nuernberg Military Tribunals 171 (United States Government Printing Office 1947). See also Grey, supra note 26, at 911-13.

${ }^{113}$ ICC Elements of Crimes art. 7(1)(g)-3, no. 2; art. 8(2)(b)(xxii)-3, no. 2; art. 8(2)(e)(vi)-3, no. 2.

${ }^{114}$ Melanie O'Brien, 'Don't Kill Them, Let's Choose Them as Wives': The Development of the Crimes of Forced Marriage, Sexual Slavery and Enforced Prostitution in International Criminal Law, 20 INT'L J. HuM. RTs. 386, 397 (2016).

${ }^{115}$ Amnesty International, Peru: The Truth and Reconciliation Commission: A First Step Towards a Country Without Injustice, at 19-21 (2004), https://www.amnesty.org/en/documents/AMR46/003/2004/en/; Jocelyn E. Getgen, Untold Truths: The Exclusion of Enforced Sterilizations From the Peruvian Truth Commission's Final Report, 29 B. C. THIRD WORLD L. J. 1 (2009).
} 
approach would conceal the reproductive aspect, namely the potentially permanent loss of reproductive capacity. Therefore, genital mutilations should also be charged separately as enforced sterilization in appropriate cases.

\section{Challenges Ahead: Re-Thinking Sexual and Non-Sexual Gender-Based Crimes Under International Law}

As demonstrated in the previous section, much attention has been devoted to sexual and genderbased crimes at the ICC in recent years. While some innovative approaches have been advanced, an analysis of the ICC's jurisprudence reveals that a clear understanding of what constitutes an act of sexual violence or gender-based violence and the relation between these concepts has not been established. In order to prosecute these crimes in an adequate manner, however, a functional and gender-sensitive conceptualization of what makes an act of violence sexual in nature is imperative.

In this regard, the ICC Elements of Crimes simply refer to "an act of a sexual nature", but do not provide any further guidance. ${ }^{116}$ In the light of the inconsistent jurisprudence, different approaches have been put forward in order to determine what constitutes an act of sexual violence. Alexander Schwarz asserted that an act is sexual in nature when it targets a person's sexual characteristics or his or her sexuality, violates the value of sexual autonomy or is sexually motivated. ${ }^{117}$ This definition is based on the 1998 report on conflict-related rape, sexual slavery and similar practices by the UN Special Rapporteur on Contemporary Forms of Slavery, which defined sexual violence as "any violence, physical or psychological, carried out through sexual means or by targeting sexuality." 118 It stated that "sexual violence covers both physical and psychological attacks directed at a person's sexual characteristics, such as forcing a person to strip naked in public, mutilating a person's genitals, or slicing off a woman's breasts"119 as well as "situations in which two victims are forced to perform sexual acts on one another or to harm one another in a sexual manner." ${ }^{20}$ Anne-Marie de Brouwer, in her analysis of the ad hoc tribunals' jurisprudence, emphasized that sexual violence does not necessarily involve physical contact, calling for a broad interpretation of the crime. ${ }^{121}$ Kai Ambos instead put forward a more restrictive definition that would require some form of physical conduct, pointing out that dignity violations are criminalized in their own right. ${ }^{122}$ Rosemary Grey highlighted the importance of culturally sensitive and local perspectives to the assessment. ${ }^{123}$ With a similar goal, the Women's Initiatives for Gender Justice, which originated from the Women's Caucus, launched the "Call It What It Is" initiative, in which it adopted an inclusive and survivor-centric approach. By conducting consultations with civil society organizations, academics, legal practitioners, policy makers, and survivors of sexual violence, this project aimed to develop a comprehensive definition of sexual violence. The resulting The Hague Principles on Sexual Violence ${ }^{124}$ follow a broad interpretation of sexual violence and refer,

\footnotetext{
${ }^{116}$ ICC Elements of Crimes art. 7(1)(g)-6, no. 1; art. 8(2)(b)(xxii)-6, no. 1; art. 8(2)(e)(vi)-6, no. 1. For a more detailed analysis of the different approaches to define sexual violence in jurisprudence and literature, see ALTUNJAN, supra note 1, at $280-85$.

${ }^{117}$ SCHWARZ, supra note 6, at 281-88. Similarly, see Christopher K. Hall et al., supra note 79, Article 7 margin no. 68.

${ }^{118}$ Comm'n on Hum. Rts., Final Rep. Submitted by Ms. Gay J. McDougall, Special Rapporteur on Contemporary Forms of Slavery: Systematic Rape, Sexual Slavery and Slavery-Like Practices During Armed Conflict, U.N. Doc. E/CN.4/Sub.2/1998/13, para. 21 (1998).

${ }^{119} I d$. at para. 21.

${ }^{120} I d$. at para. 22.

${ }^{121}$ De Brouwer, supra note 6, at 147-51; See also Grey, supra note 79, at 284, criticizing the "overreliance on penetration as the determinative factor."

${ }^{122}$ Kai Ambos, Treatise on International Criminal Law, Vol 2: The Crimes and Sentencing 103-104 (2013). Similarly, see SCHWARZ, supra note 6, at 338-42.

${ }^{123} \mathrm{GREY}$, supra note 22 , at 321 . See also Grey, supra note 79.

${ }^{124}$ The Hague Principles on Sexual Violence, at 4 (2019), https://4genderjustice.org/wp-content/uploads/2019/11/TheHague-Principles-on-Sexual-Violence.pdf.
} 
for example, to the perpetrator's motivation, the impact on the victim's sexual autonomy, sexual orientation, gender identity, or reproductive capacity or autonomy, as well as the use of sexual innuendos or language. ${ }^{125}$ In compiling a detailed list of acts of sexual violence, the Principles will certainly contribute to a more nuanced and comprehensive understanding of sexual violence and serve as guidance for future international trials.

Some of these approaches, however, do not adequately distinguish sexual violence from the related concept of gender-based violence, which more broadly refers to violence committed because of the victim's gender and thus also encompasses non-sexual manifestations. An important example is reproductive violence, which can be defined as violence affecting the victim's reproductive autonomy, meaning one's freedom to choose whether, how, and under what circumstances to reproduce. ${ }^{126}$ The ICC Statute encompasses two explicit reproductive crimes, forced pregnancy and enforced sterilization. Both crimes do not necessarily affect the victim's sexual autonomy, but primarily interfere with the ability to make reproductive choices. Nevertheless, the ICC Statute lists these crimes within its provisions on sexual crimes. This allows for the conclusion that the concept of sexual violence must be understood broadly. At the same time, however, an overly extensive interpretation of what constitutes an act of sexual violence is problematic with regard to the principle of legality. ${ }^{127}$ Furthermore, it may prove impractical and thus counterproductive in practice. ${ }^{128}$

Against this background, an act should be considered as sexual in nature for the purposes of the ICC Statute when it violates the victim's sexual or reproductive autonomy, ${ }^{129}$ meaning the freedom to decide whether, how, and under what circumstances to engage in sexual activity or to reproduce. This is the case when an act is committed through sexualized means, when it has an impact on the victim's sexual or reproductive organs or functions, or when the victim is targeted precisely because of his or her sexual or reproductive organs or functions.

\section{E. Conclusion}

A survey of the ICC's jurisprudence on sexual crimes shows that even the most progressive legal framework is futile when it is not translated into legal practice. In the case of sexual and genderbased crimes under international law, this requires constant effort, prioritization, and a high degree of gender sensitivity within both the prosecution and the judiciary. In the ICC's early years, many of the problems surrounding charges of sexual violence could be traced back to ineffective and gender-blind investigations. Moreover, some of the ICC's early decisions were informed by inadequate understandings of sexual violence, the concept of intersectionality, and the gendered harms suffered by victims in conflict scenarios. Because of all these factors, the ICC's track record on sexual and gender-based crimes is dire.

Nevertheless, the gap between aspirations and reality concerning the prosecution of sexual crimes at the ICC has shrunk. First, it can be observed that expectations as to what the ICC can achieve have decreased. Indeed, the idea that the ICC would put an end to impunity for conflict-related sexual violence was unrealistic from the outset, not least because the ICC is constrained by jurisdictional restrictions, limited resources, and its dependence on state cooperation. In a more realistic light, the ICC can only be expected to contribute to the fight

\footnotetext{
${ }^{125} I d$. at 7.

${ }^{126}$ See Andrea Büchler, Reproduktive Autonomie und Selbstbestimmung: Dimensionen, Umfang Und Grenzen AN DEN ANFÄNGEN MENSCHLICHEN LEBENS 5 (2017). See generally on reproductive crimes under international law ALTUNJAN, supra note 1.

${ }^{127}$ See also AMBOS, supra note 122, at 103; SCHWARZ, supra note 6, at 277; WERLE \& JEßBERGER, supra note 5, margin no. 1099.

${ }^{128}$ See AltunJAN, supra note 1, at 282-84. See also GREY, supra note 22, at 318-21; SCHWARZ, supra note 6, at 347.

${ }^{129}$ See also Kai Ambos, Sexuelle Gewalt in bewaffneten Konflikten und Völkerstrafrecht, ZEITSCHRIFT FÜR INTERNATIONALE STRAFRECHTSDOGMATIK 287, 288 (2011).
} 
against conflict-related sexual violence. This can be achieved by way of developing and consolidating a gender-sensitive legal framework and jurisprudence, which may serve as a guidance point for international criminal law and as a model for domestic jurisdictions. Second, recent decisions demonstrate that the ICC is able to address sexual violence in an adequate manner. This Article has highlighted some progressive developments, most notably in the cases against Ntaganda, Ongwen, and Al Hassan. Most notably, the judgment against Dominic Ongwen succeeded in painting a comprehensive picture of sexual and gender-based crimes suffered by victims and constitutes important precedent for future cases. Progress is also visible within the Office of the Prosecutor, whose Policy Paper has noticeably influenced the more recent investigations and prosecutions. This illustrates, again, that a court's success in prosecuting gender-based violence depends on its officials' sensitivity towards gender issues. ${ }^{130}$ It is to be hoped that the third ICC Prosecutor, Karim Khan, will continue to institutionalize the prioritization of sexual violence within the prosecution's mandate. At the same time, with more cases involving sexual crimes reaching the trial and appeals stages, the ICC judges will have more opportunities to clarify and enhance their conceptualization of sexual crimes as well as non-sexual manifestations of gender-based violence.

\footnotetext{
${ }^{130}$ Oosterveld, supra note 26 , at 259.
} 